\title{
ANALISIS DAMPAK INDUSTRI 4.0 TERHADAP SISTEM PENGAWASAN KETENAGANUKLIRAN DI INDONESIA
}

\author{
Reno Alamsyah ${ }^{1}$ \\ 1) Pusat Pengkajian Sistem Teknologi Pengawasan Instalasi dan Bahan Nuklir \\ (P2STPIBN), BAPETEN, Jakarta, Indonesia, r.alamsyah@bapeten.go.id
}

\begin{abstract}
ABSTRAK
ANALISIS DAMPAK INDUSTRI 4.0 TERHADAP SISTEM PENGAWASAN KETENAGANUKLIRAN DI INDONESIA. Telah dilakukan suatu kajian mengenai pengaruh gelombang Industri 4.0 terhadap sistem pengawasan ketenaganukliran di Indonesia. Industri 4.0 adalah istilah yang diterapkan pada berbagai transformasi yang demikian cepat dalam desain, manufaktur, operasi, serta layanan produk dan sistem produksi. Penggunaan 4.0 menandakan bahwa ini adalah revolusi industri keempat di dunia, meneruskan tiga lompatan besar sebelumnya, yatu: Manufaktur mesin uap dan air, produksi massal bertenaga listrik berbasis pembagian kerja, dan zaman elektronika dan teknologi informasi dengan otomatisasi tugastugas rumit. Berbagai penelitian menyebutkan bahwa Industri 4.0 mengubah banyak hal, termasuk: meningkatnya fleksibilitas produksi, kustomisasi massal, produktivitas, mutu produk, keterlibatan pelanggan dalam proses desain, semakin mendekatnya lokasi produksi ke pelanggan, dan model bisnis. Semua perkembangan ini tentunya harus diantisipasi oleh Badan Pengawas. Dengan demikian, tujuan dari kajian ini adalah untuk mengevaluasi hal-hal yang sudah atau perlu dilakukan oleh BAPETEN dalam rangka menyongsong era Industri 4.0. Kajian dilakukan dengan metode deskriptif, analitik dan kualitatif yang dilengkapi dengan studi literatur dan pengamatan praktik-praktik yang ada di BAPETEN. Kajian ini menyimpulkan bahwa BAPETEN sebagian telah melakukan antisipasi akan datangnya era Industri 4.0, namun masih ada banyak peluang untuk peningkatan.
\end{abstract}

Kata kunci: Industri 4.0, produktivitas, pengawasan ketenaganukliran.

\section{ABSTRACT}

ANALYSIS OF THE IMPACT OF INDUSTRY 4.0 ON THE NUCLEAR ENERGY REGULATORY SYSTEM IN INDONESIA. The study of the effects of the Industrial wave 4.0 on nuclear regulatory systems in Indonesia has been carried out. Industry 4.0 is a term applied to a revolution or such a rapid cahanges in the design, manufacture, operation, and service of manufacturing systems and products. The use of 4.0 signifies that this is the fourth industrial revolution in the world, continuing three previous giant leaps: Manufacturing of steam and water mechanics, electrically powered mass production based on labor division, and the age of electronics and information technology with the automation of complex tasks. Some studies have suggested that Industry 4.0 changes many things, including: increased production flexibility, mass customization, productivity, product quality, customer engagement in the design process, shortening the production sites to the customers, and the business models. All these developments must be anticipated by the Regulatory Body. Thus, the purpose of this study is to evaluate the items that are or should be done by BAPETEN in order to anticipate the Industry 4.0 era. The study was conducted by descriptive, analytic and qualitative methods which were completed with literature study and observation of existing practices at BAPETEN. From this study it can be concluded that BAPETEN has partially anticipated the coming of Industry 4.0 era and there are still many opportunities for improvement.

Key words: Industry 4.0, productivity, nuclear regulation 


\section{PENDAHULUAN}

Industri 4.0 adalah istilah yang saat ini umum digunakan untuk revolusi industri ke-4. Berbagai studi ${ }^{1-5}$ menjelaskan bahwa revolusi pertama yang dimulai dengan penemuan mesin uap pada tahun 1780an berkembang hingga pertengahan abad XIX berbasis industri mekanik berdaya air dan uap. Pada akhir abad XIX revolusi kedua ditandai dengan kemampuan produksi massal dengan tenaga listrik berbasis pembagian kerja (assembly line). Kemudian, pada tahun 1970an dimulai era revolusi ketiga dengan otomasi pekerjaanpekerjaan kompleks didukung teknologi elektronik dan informasi. Saat ini dikatakan revolusi keempat ditandai dengan kemampuan teknologi sensor, keterhubungan (interconnectivity) dan analisis data yang memungkinkan kustomisasi (customization) massal, integrasi rantai pasokan dan efisiensi lebih tinggi berbasis sistem cyber-physical. Dengan kata lain, Industri 4.0 adalah transformasi yang demikian cepat dalam desain, manufaktur, operasi, sertra layanan produk dan sistem produksi. Studi-studi tersebut juga menyebutkan bahwa Industri 4.0 mengubah banyak hal, termasuk: meningkatnya fleksibilitas produksi, kustomisasi massal, produktivitas, mutu produk, keterlibatan pelanggan dalam proses desain, semakin mendekatnya lokasi produksi ke pelanggan, dan model bisnis.

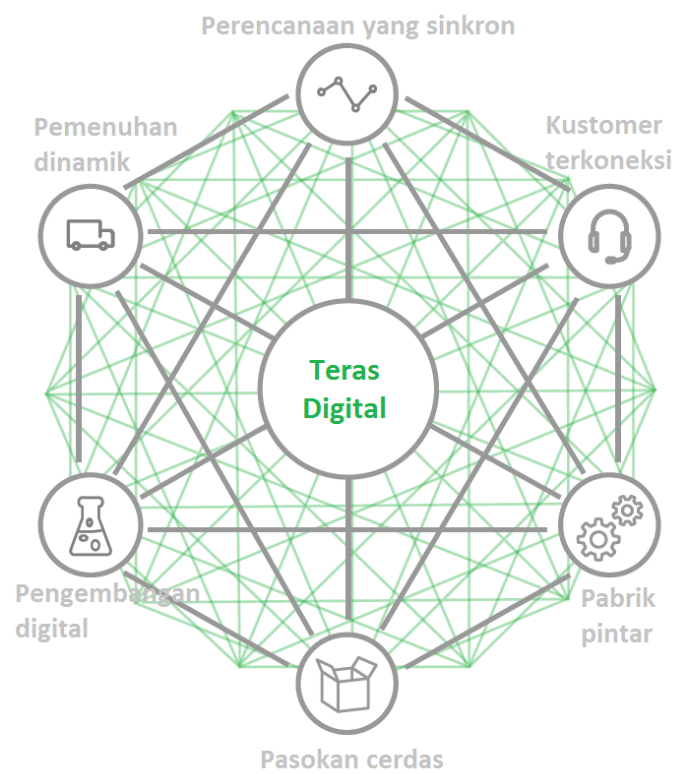

Gambar 1. Jaringan Pasokan Secara Digital ${ }^{4}$
Gambar 1 di atas menjelaskan jaringan pasokan secara digital yang menjadi salah satu ciri khas dari Industri 4.0. Di sini digambarkan peran sentral teras digital dalam mengomunikasikan satu sama lain antara keinginan pelanggan, perencanan, pabrik dan sistem pasokan yang cerdas, pengembangan secara digital, serta pemenuhan secara dinamik. Gambar 2 berikut kemudian melukiskan adanya sembilan teknologi yang menguatkan Industri 4.0 dan mentransformasi produksi industrial, yaitu: robot mandiri, simulasi, sistem integrasi, internet untuk segala (The Industrial Internet of Things), keamanan dunia maya, awan (The cloud), manufaktur aditif (Additive manufacturing), relitas tambahan (Augmented reality), serta data besar dan analitika. Kedua gambar ini menjelaskan pula cepatnya transformasi industrial yang terjadi.

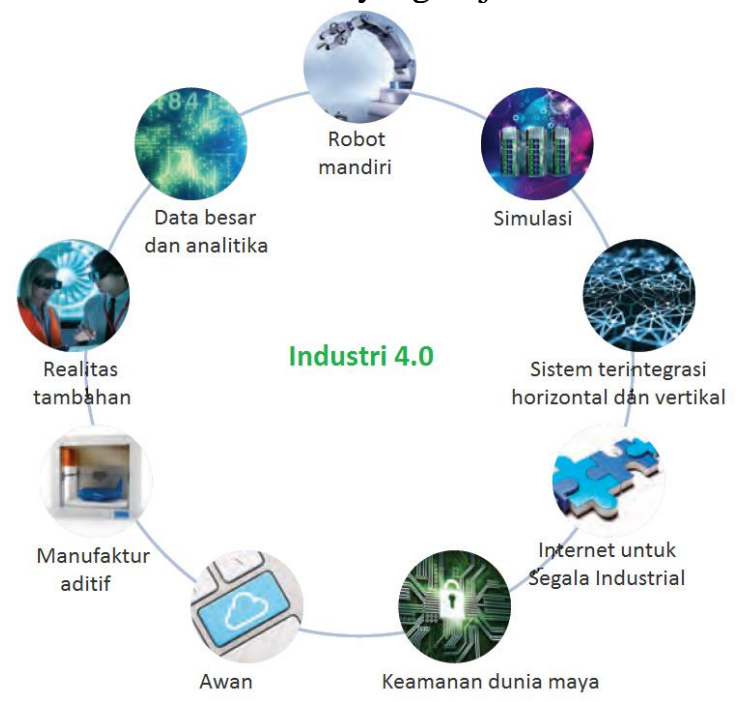

Gambar 2. Sembilan Teknologi yang

Mengubah Produksi Industrial ${ }^{5}$

Dalam perubahan cepat ini, Indonesia tanpa terkecuali harus mengadapsi Industri 4.0. Untuk itu, Kementerian Perindustrian telah menerbitkan dan mengembangkan beleid Indonesia $4.0^{6,7}$. Dikatakan bahwa langkahlangkah ini adalah untuk melipatgandakan produkstivitas dan ekspor, membuka banyak lapangan kerja, sehingga Indonesia menjadi salah satu dari 10 besar ekonomi dunia.

Perubahan arah dan pola industri di Indonesia dan kebijakan tersebut di atas tentu akan berpengaruh terhadap pengawasan ketenaganukliran. Sebab, arus barang termasuk yang memanfaatkan ataupun terkait dengan tenaga nuklir, baik impor maupun ekspor, ataupun pengalihan secara domestik, akan 
semakin meningkat. Sehingga, hubungan antara BAPETEN dengan pihak-pihak berkepentingan, termasuk pemohon izin atau persetujuan, haruslah sedemikian sehingga kelancaran pengawasan, dalam perizinan maupun inspeksi, dapat ditingkatkan dengan tetap menjamin aspek keselamatan dan keamanan nuklir maupun seifgard.

Dengan demikian, tujuan dari penulisan makalah ini adalah untuk mengevaluasi hal-hal yang sudah atau perlu dilakukan oleh BAPETEN dalam rangka menyongsong era Industri 4.0. Hal ini penting untuk dilakukan, karena hasilnya diharapkan dapat memberikan kontribusi yang signifikan terhadap kebijakan Pemerintah mengenai Indonesia 4.0, sekaligus meningkatkan efektivitas dan efisiensi pengawasan ketenaganukliran.

\section{METODE}

Kajian ini dilakukan dengan metode yang bersifat deskriptif, analitik dan kualitatif, serta dilengkapi dengan studi literatur dan pengamatan praktik-praktik perizinan dan inspeksi yang dilakukan di BAPETEN, termasuk teknologi informasi yang mendukungnya. Pokok-pokok yang dibahas pada kajian ini adalah pemetaan lingkungan strategis BAPETEN dalam kerangka Industri 4.0 atau Indonesia 4.0, identifikasi tantangan dan ancaman yang akan dihadapi, serta analisis penerapan di BAPETEN.

Sebagai langkah awal, lingkungan strategis BAPETEN perlu diidentifikasi guna menjalankan Sistem Manajemen BAPETEN ${ }^{8}$ yang salah satunya bertujuan untuk memenuhi harapan pihak-pihak berkepentingan. Pemetaan ini akan melihat sifat keterhubungan maupun cara atau metode hubungan tersebut dilakukan secara efektif dan efisien. Dengan peta yang baik, maka BAPETEN diharapkan dapat meningkatkan mutu perencanaan kegiatan yang akan dilakukannya.

Kajian dilanjutkan dengan studi literatur tentang tantangan dan bahkan ancaman dalam menghadapi Industri 4.0. Pemilahan atas tantangan dalan ancaman dilakukan karena banyak dan luasnya topik penelitian internasional tentang Industri 4.0 yang telah dilakukan. Kriteria pemilahan adalah kesesuaian dengan proses bisnis BAPETEN sebagai lembaga pengawasan bidang keselamatan dan keamanan nuklir, serta seifgard. Peluang-peluang dalam
Industri 4.0 tidak dibahas pada makalah ini karena diasumsikan telah dimuat dalam kebijakan Indonesia 4.0

Pada bagian akhir kajian dilakukan analisis atas kegiatan terkait Industri $4.0 \mathrm{di}$ BAPETEN, baik yang sudah maupun belum dilakukan, terhadap tantangan dan ancaman yang telah diidentifikasi sebelumnya. Dari analisis ini, diidentifikasikan langkah-langkah perbaikan Kemudian, koordinasi BAPETEN dengan lingkungan strategisnya juga dibahas.

\section{HASIL DAN PEMBAHASAN}

\section{Lingkungan strategis}

Kementerian Perindustrian RI yang mengusung kebijakan Indonesia 4.0 adalah instansi yang mengoordinasikan pelaksanaan Industri 4.0. Dokumen Indonesia 4.0 menargetkan agar Indonesia menjadi 10 besar kekuatan ekonomi dunia berdasarkan PDB pada tahun 2030. Strategi yang diterapkan adalah dengan menggandakan rasio produktivitasterhadap-biaya, mendorong ekspor netto menjadi $10 \%$ dari PDB, danmenganggarkan $2 \%$ PDB untuk penelitian dan pengembangan. Dengan demikian, setiap Kemeterian atau Lembaga $(\mathrm{K} / \mathrm{L})$, termasuk BAPETEN, harus menyusun agenda kerja terkait Industri 4.0.

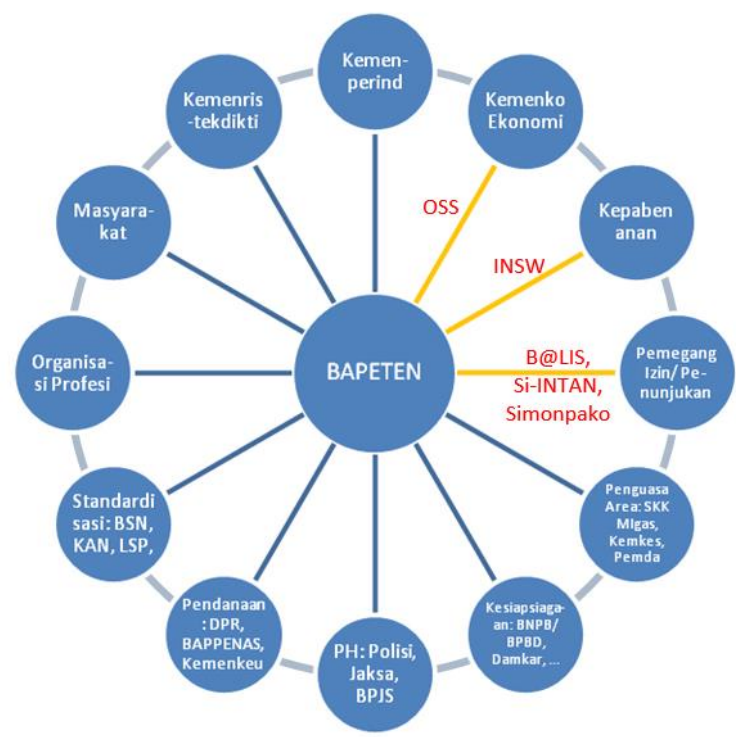

Gambar 3. Lingkungan Strategis BAPETEN dalam Indonesia 4.0

Seperti yang dijelaskan pada Gambar 3 di atas, lingkungan strategis BAPETEN yang telah terhubung daring (online) adalah dengan Kementerian Koordinator bidang 
Perekonomian dalam rangka perizinan satu atap melalui pelantar (platform) Online Single Submission (OSS) ${ }^{9}$, dengan K/L terkait perizinan ekspor-impor secara terintegrasi melalui Indonesia National Single Window $(\mathrm{INSW})^{10,11}$, dan dengan pemohon atau pemegang izin atau ketetapan BAPETEN dengan berbagai pelantar seperti BAPETEN Licensing and Inspection System (B@LIS) ${ }^{12}$, Sistem Informasi Data Dosis Pasien Nasional $(\text { Si-INTAN })^{13}$, dan Sistem Montoring Parameter Keselamatan Operasional $\left(\right.$ SIMONPAKO) ${ }^{14}$.

Dalam pelaksanaan kebijakan pengawasan, BAPETEN juga harus berkoordinasi dengan penguasa area, seperti: dalam bidang kesehatan dengan Kementerian Kesehatan, dalam bidang minyak dan gas dengan SKK Migas, dan dalam hal penanganan masalah bahan radioaktif alami yang diperkuat teknologi (TENORM) dengan berbagai Pemerintah Daerah. Tanpa koordinasi yang erat, maka kebijakan-kebijakan pengawasan BAPETEN menjadi sangat sulit untuk dilaksanakan di lapangan. Belum ada komunikasi digital yang menghubungkan berbagai instansi terkait ini dengan BAPETEN, sebagaimana juga untuk semua instansi yang akan dijelaskan berikut ini:

a. Dalam hal kesiapsiagaan dan penanggulangan kedaruratan nuklir atau radiologi, BAPETEN bekerjasama dengan BNPB dan BPBD, penanggap darurat seperti pemadam kebakaran dan tim SAR, kepolisian, ambulan, laboratorium forensik, dsb.

b. Untuk penegakan hukum bekerja sama dengan kepolisian, kejaksaan, dan bahkan dengan BPJS Kesehatan. Pengamatan di lapangan menunjukkan bahwa BPJS tidak akan melakukan pembayaran untuk pelayanan yang menggunakan sumber radiasi jika tidak memiliki izin dari BAPETEN dan para staf terlibat belum mendapat pelatihan proteksi radiasi.

c. Koordinasi dalam perencanaan kegiatan dan anggaran dengan DPR, BAPPENAS dan Kementerian Keuangan. Dalam hal ini, harus diingat bahwa perubahan kebijakan anggaran pada tahun-tahun terakhir ini sangatlah cepat.

d. Dalam hal standardisasi dengan BSN, KAN, dan lembaga sertifikasi produk maupun profesi, serta kementerian terkait.

e. Untuk menjamin tersedianya tenaga profesi terkait ketenaganukliran bekerja sama dengan berbagai organisasi profesi seperti: radiografer; fisikawan medik; dokter spesialis radiologi, radioterapi dan kedokteran nuklir.

f. Dalam rangka pelaksanaan kebijakan transparansi dan keterbukaan dengan masyarakat secara umum. Untuk pengadaan barang dan jasa, BAPETEN mengikuti kebijakan Pemerintah tentang $e$ procurement dengan Peraturan Kepala BAPETEN No. 15 Tahun 2012 tentang Unit Layanan Pengadaan BAPETEN ${ }^{15}$.

g. Koordinasi kebijakan teknologi nasional dengan Kemenristekdikti, termasuk dalam hal pengembangan Nuclear Energy Programme Implementing Organization (NEPIO) bersama ESDM, PLN, KLH, dan $\mathrm{K} / \mathrm{L}$ terkait lainnya.

Dari tiga koordinasi yang telah terhubung melalui jaringan, inisiatif pembentukan OSS dan INSW bukan berasal dari BAPETEN. Untuk koordinasi lain yang belum terhubung via internet, BAPETEN dapat mengusulkan pembuatan pelantar komunikasi yang dibutuhkan, atau berinisiatif membangun pelantar tersebut sesuai dengan sifat koordinasi yang dihadapi. Bagaimanapun juga, sikap pro aktif BAPETEN sangat dibutuhkan dalam menghadapi perubahan yang begitu cepat di era Industri atau Indonesia 4.0 ini.

\section{Tantangan dan ancaman}

Berbagai tantangan dan bahkan ancaman dalam menghadapi era Industri 4.0 telah diidentifikasi pada beberapa kajian internasional $^{2,16-18}$. Tidak semua tantangan dan ancaman yang teridentifikasi itu sesuai dengan tugas dan fungsi BAPETEN. Jika dievaluasi lebih jauh, maka tantangan yang dihadapi BAPETEN pada era Industri 4.0, sebagaimana dilukiskan pada Gambar 4, adalah terkait infrastruktur fisik, pengorganisasian kegiatan, pengembangan SDM, kepemimpinan dan koordinasi, serta peraturan dan standardisasi. Kemudian, ancaman yang dihadapi adalah berhubungan dengan keamanan berkomputer dan dunia maya, dan kepemilikan data dan informasi.

Tantangan infrastruktur fisik yang harus dibangun BAPETEN adalah sistem dan jejaring cerdas, mobilitas, fleksibilitas dan interoperabilitas antar sistem, dan integrasi pihak- 
pihak berkepentingan. Dengan pengembangan infrastruktur fisik itu, maka pola dan sistim kerja akan berubah. Contoh yang sudah dilakukan di BAPETEN adalah evaluasi dokumen perizinan secara daring melalui pelantar B@LIS. Kemudian, pengembangan SDM juga menjadi hal yang sangat penting, terutama terkait perilaku dalam menghadapi perubahan yang demikian cepat, bekerja dalam jaringan, termasuk aspek keamanan informasi dan berkomputer, hingga aspek-aspek hukum yang terkait.

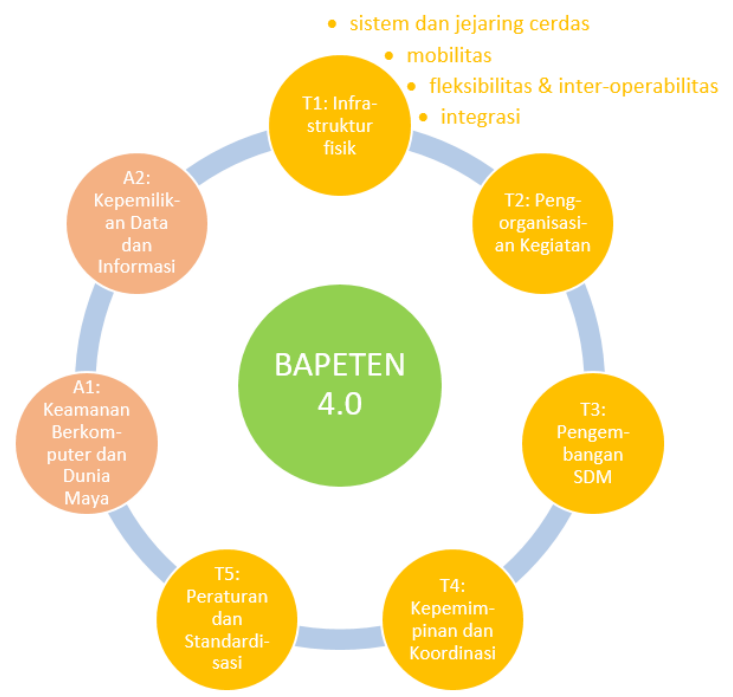

Gambar 4. Tantangan dan Ancaman BAPETEN dalam Industri 4.0

Tantangan berikutnya adalah tentang kepemimpinan dan koordinasi. Dalam hal ini, arus perubahan yang cepat menuntut keputusan yang segera dan tepat dalam menyusun strategi perubahan, di dalam organisasi maupun pada skala nasional, serta teknologi yang akan dipilih. Hal itu tentu saja memerlukan kepemimpinan yang pro-aktif dalam mengkoordinasikan pengelolaan kegiatan.

Peraturan dan standardisasi adalah tantangan berikutnya yang memuat internalisasi dan institusionalisasi dari Industri 4.0 dan Indonesia 4.0 menjadi BAPETEN 4.0. Di dalamnya termasuk juga mekanisme untuk menjawab semua tantangan dan ancaman yang ada, antar muka komunikasi dan koordinasi dengan pihak-pihak berkepentingan, serta pengaturan terkait konflik kepentingan.

Ancaman yang mungkin dihadapi BAPETEN terkait keamanan berkomputer dan dunia maya adalah nyata dihadapi, tanpa dan/atau (akan menjadi lebih besar lagi) dengan
Industri 4.0. Menurut T. Pereira et al. ${ }^{16}$, ancaman tersebut dapat dalam bentuk spionase cyber, kebocoran informasi rahasia dan/atau yang memiliki hak intelektual, serta penolakan layanan digital (Denial-of-Service/DOS), yang dapat terjadi antara lain karena suatu laman dibanjiri permohonan layanan fiktif pada saat yang sama, sehingga permohonan yang sebenarnya tidak dapat diminta melalui laman yang macet tersebut. Kejahatan lainnya di dunia maya yang mungkin terjadi antara lain adalah hacking dan cracking, defacing, phising, spamming, malware, penyebaran virus, data forgery, serta sabotase dan extortion.

\section{Pembuatan dan pengembangan}

Gambar 3 telah menjelaskan bahwa sebagian besar antarmuka BAPETEN dengan lingkungan strategisnya belum terhubung melalui suatu pelantar tertentu. Dalam hal ini, pembuatan pelantar dapat direncanakan secara bertahap dengan memerhatikan tingkat urgensi keterhubungan masin-masing. Di samping itu, pengembangan dapat dilakukan untuk pelantar yang BAPETEN menjadi inisiatornya, seperti: B @LIS, Si-INTAN dan SIMONPAKO. Untuk pelantar yang BAPETEN bukan inisiatornya, seperti OSS dan INSW, pengembangan hanya dapat dilakukan melalui koordinasi dengan instansi yang bersangkutan. Pembuatan dan pengembangan ini haruslah mempertimbangkan tantangan dan ancaman sebagaimana telah dibicarakan pada fasal sebelumnya.

Dengan demikian, ada banyak peluang peningkatan bagi pelantar yang telah dikembangkan BAPETEN. Berikut adalah beberapa contoh butir-butir yang dapat digunakan untuk mengevaluasi dan mengembangkan pelantar tersebut sesuai dengan tantangan dan ancaman yang telah teridentifikasi.

a. Sistem cerdas: Apakah pelantar dapat mengidentifikasi kemungkinan kesalahan pemasukan data dan duplikasi informasi? Apakah sistem dapat menampilkan statistik yang diperlukan dan melakukan prediksi? Apakah sistem memberi peringatan tertentu terkait dengan penegakan hukum (jatuh tempo izin, pelanggaran berat, dsb.)?

b. Jejaring cerdas: Apakah pelantar menggunakan jaringan teknologi internet terbaik? Apakah sistem dapat bekerja di dalam maupun di luar jaringan? Apakah pengindera cerdas juga digunakan? 
c. Mobilitas: Apakah pengambilan data di lapangan (inspeksi) dapat dilakukan dengan bantuan telepon pintar dan tablet? Sistem pemindaian barcode digunakan? Laporan lengkap dapat diselesaikan di lapangan?

d. Fleksibilitas dan interoperabilitas antar sistem: Apakah pelantar dapat dioperasikan dengan sistem operasi dan berbagai moda gawai yang berbeda?

e. Integrasi pihak-pihak berkepentingan: Apakah pelantar dapat diakses, dilihat dan/atau diedit, oleh semua pihak berkepentingan sesuai dengan tingkat kepentingannya?

f. Keamanan berkomputer dan dunia maya: Apakah sudah ada analisis risiko dan pencegahan mengenai bocornya informasi pengawasan (bersifat rahasia dan/atau memiliki hak cipta) tangan yang tidak bertanggung-jawab, serta penanggulangan jika hal itu terjadi? Pencegahan dan penanggulangan DOS, dan kejahatan dunia maya lainnya?

g. Kepemilikan data dan informasi: Apakah sudah ada pengaturan kepada pihak-pihak berkepentingan mengenai kepemilikan data dan informasi yang didapat selama proses pengawasan?

h. Standardisasi: Apakah sudah ada standar 9 jenis teknologi sebagaimana dilukiskan pada Gambar 2? Standar layanan telah dikembangkan sejalan dengan Indonesia 4.0 dan kebijakan lain dari Pemerintah?

i. Pengorganisasian kegiatan: Apakah sistim kerja daring telah dipastikan tidak mengurangi hak-hak pegawai, sesuai dengan peraturan perundang-undangan kepegawaian nasional?

j. Pengembangan SDM: Apakah SDM telah dikembangkan sesuai dengan prinsip interaksi antara Individu, Teknologi dan Organisasi (ITO)?

k. Kepemimpinan dan koordinasi: Apakah agenda Indonesia 4.0 telah dituangkan dalam rencana strategis mendukung visi dan misi BAPETEN? Apakah koordinasi nasional telah dilakukan kepada semua $\mathrm{K} / \mathrm{L}$ terkait Indonesia 4.0 sebagaimana diuraikan pada Gambar 3?

1. Peraturan: Apakah telah dikembangkan peraturan perundang-undangan, internal maupun eksternal, telah dilengkapi untuk melaksanakan Indonesia 4.0 atau BAPETEN 4.0 sedemikian sehingga semua tantangan dan ancaman dapat dikelola secara optimal dengan tetap menjamin pengawasan yang mangkus dan sangkil?

Pertanyaan-pertanyaan di atas dapat terus dikembangkan sesuai kebutuhan jika kebijakan Indonesia 4.0 telah diadopsi di BAPETEN. Satu tantangan lain yang tak kalah pentingnya adalah dalam mengevaluasi dan mengadopsi sembilan teknologi yang disebutkan pada Gambar 2 dan dinilai cocok untuk digunakan di BAPETEN.

\section{KESIMPULAN}

Makalah ini telah menguraikan pengaruh Industri 4.0 atau Indonesia 4.0 terhadap pengawasan BAPETEN. Untuk pengembangan lebih lanjut telah dilakukan analisis lingkungan strategis, tantangan dan ancaman yang sesuai. Dengan demikian, dapat disimpulkan bahwa BAPETEN sebagian telah melakukan antisipasi akan datangnya era Industri 4.0, namun masih ada banyak peluang untuk peningkatan dengan memerhatikan semua tantangan dan ancaman yeng telah teridentifikasi.

\section{UCAPAN TERIMAKASIH}

Penulis menucapkan terima kasih banyak kepada jajaran Manajemen P2STPIBN yang telah mendukung dan memberikan kesempatan seluas-luasnya kepada penulis untuk melakukan kajian ini.

\section{DAFTAR PUSTAKA}

1. Ron Davies, Industry 4.0 Digitalisation for productivity and growth, European Parliamentary Research Service, 2015.

2. CGI, Industry 4.0 Making your business more competitive, CGI Group Inc., 2017.

3. Dragan Vuksanović et al., "Industry 4.0: The Future Concepts and New Visions of Factory of the Future Development," in International Scientific Conference on ICT and E-Business Related Research, 2016, pp. 293-298.

4. Matthew Budman and Abrar Khan, Forces of change: Industry 4.0, Deloitte Insight, 2017.

5. Michael Rüßmann et al., Industry 4.0 The Future of Productivity and Growth in Manufacturing Industries, The Boston Consulting Group, 2015. 
6. Kemeterian Perindustrian RI, (13 July 2018), Making Indonesia 4.0. Available: www.kemenperin.go.id/download/18384.

7. Kemeterian Perindustrian RI, (13 July 2018), Indonesia's Fourth Industrial Revolution - Benchmarking Implementasi Industri 4.0 .4 Available: www.kemenperin.go.id/download/18449

8. Republik Indonesia, Peraturan Kepala BAPETEN No. 14 Tahun 2014 tentang Sistem Manajemen BAPETEN, BAPETEN, 2014.

9. Kemenko bidang Perekonomian RI, (13 July 2018), OSS (Online Single Submission). Available: https://ekon.go.id/press/view/siaran-persizin-berusaha.4093.html.

10. Pengelola Portal INSW Kementerian Keuangan. (13 July 2018), Indonesia Single Window.

Available: https://www.insw.go.id/index.php.

11. (noname). (13 July 2018), Welcome to Indonesia National Trade Repository. Available: http://intr.insw.go.id/.

12. BAPETEN, (13 July 2018), B @LIS online. Available:

https://balis.bapeten.go.id/portal/web/.

13. BAPETEN, (13 July 2018), Sistem INformasi daTA dosis pasieN. (SiINTAN). Available: http://idrl.bapeten.go.id/.

14. BAPETEN, (13 July 2018), SIMONPAKO Login Site. Available: http://simonpako.bapeten.go.id/simonpako/ index.php? $\mathrm{r}=$ site/login.

15. Republik Indonesia, Peraturan Kepala BAPETEN No. 15 Tahun 2012 tentang Unit Layanan Pengadaan BAPETEN, BAPETEN, 2012.

16. T. Pereira et al., "Network and Information Security Challenges within Industry 4.0 Paradigm," in Manufacturing Engineering Society International Conference, 2017, pp. 1253-1260.

17. Adel Badri et al., "Occupational health and safety in the industry 4.0 era: A cause for major concern?", Safety Science 109 (2018) 403-411.

18. Kadri-Liis Kusmin, (13 July 2018), Industry 4.0. Available: http://www.tlu.ee/ pnormak/ISA/Analytica 1\%20articles/2-Industry\%204.0\%20$\% 20$ Kusmin.pdf. 
JURNAL FORUM NUKLIR (JFN) VOLUME 12, NOMOR 2, NOVEMBER 2018 